\title{
Psoriasis Induced by Tumor Necrosis Factor- Alpha Antagonist Therapy: Case Series and Literature Overview
}

\author{
Tümör Nekrosis Faktor- Alfa inhibitörü Kullanımına Bağ|ı Olarak Gelişen \\ Psöriazis: Olgu Serisi ve Literatürün Gözden Geçirilmesi
}

\author{
Tunay Sarpel1, Sibel Başaran¹, Filiz Doğan Akçam¹, Suhan Günaştı², Yaşargül Denli2 \\ 'Çukurova Üniversitesi Tıp Fakültesi, Fiziksel Tıp ve Rehabilitasyon Anabilim Dalı, Adana, Turkey \\ Çukurova Üniversitesi Tıp Fakültesi, Dermatoloji Anabilim Dalı, Adana, Turkey
}

\section{Abstract}

Although tumor necrosis factor-alpha (TNF- $\alpha$ ) antagonists are shown to be effective in the treatment of psoriasis, induction of psoriatic skin lesions have been seen in patients with different rheumatic conditions who were treated with TNF- $\alpha$ antagonists. In this case series, we report four cases that developed psoriatic lesions; in one of the cases, psoriasis was associated with two different TNF- $\alpha$ antagonists.

Case 1: A 31-year-old man with ankylosing spondylitis developed erythematous and squamous lesions on his extremities in the 2nd week of infliximab treatment. Two months later he began to receive etanercept, and psoriatic skin lesions developed on the entire trunk and extremities, and predominantly on the scalp after one month. Case 2: A 53-year-old female with rheumatoid arthritis developed psoriatic skin lesions in the ankle region after two months' treatment with etanercept. Case 3: A 34-year-old female with ankylosing spondylitis developed psoriatic lesions on her palms after 10 months' treatment with infliximab. Case 4: A 40-year-old female with ankylosing spondylitis developed pustular lesions on her palms and soles after two years' treatment with infliximab. The patients had no personal or family history of psoriasis. The diagnosis of psoriasis was confirmed by skin biopsy in three of the cases.

Psoriatic skin lesions can be induced as a result of treatment with TNF- $\alpha$ antagonists in patients with rheumatoid arthritis, ankylosing spondylitis and other spondyloarthropathies. The most common form is plaque or pustular pattern with palmoplantar distribution. (Turk J Rheumatol 2010; 25: 91-4)

Key words: Ankylosing spondylitis, psoriasis, rheumatoid arthritis, spondyloarthropathy, TNF-alpha antagonists

Received: 26.12 .2008

Accepted: 16.03 .2009

\section{Özet}

Tümör nekrozis faktor-alfa (TNF-alfa) inhibitörleri psöriazisin tedavisinde etkili olmasına rağmen TNF-alfa inhibitörleri ile tedavi edilen çșitli romatizmal hastalıklarda psöriazisin indüklenebildiği bildirilmektedir. Bu olgu serisinde hastaların birinde iki farklı TNF-alfa inhibitörü kullanımına bağlı olmak üzere dört hastada ilaca bağlı olarak gelișen psöriazis vakaları sunulmaktadır. Vaka 1: Ankilozan spondilit tanısıyla takip edilen ve infliksimab tedavisi bașlanan 31 yașında erkek hastada tedavinin 2.haftasında ekstremitelerde eritemli skuamlı lezyonlar geliști. Iki ay sonra tekrar bașlanan etanersept tedavisinin 1. ayında ise saçlı deride yoğun olmak üzere tüm gövde ve ekstremitelerde psöriatik lezyonlar geliști. Vaka 2: Romatoid artritli 53 yașında bayan hastada etanersept tedavisinin 2.ayında her iki ayak bileği çevresinde eritemli skuamlı lezyonlar oluștu. Vaka 3: Ankilozan spondilitli 34 yașında bayan hastada infliksimab tedavisinin 10.ayında her iki elinde palmar psöriatik lezyonlar geliști. Vaka 4: Ankilozan spondilit tanısıyla takip edilen 40 yașında bayan hastada infliksimab tedavisinin 2.yılında el ve ayaklarında püstüler lezyonlar geliști. Hastaların hiçbirinde psöriazis için aile öyküsü yoktu. Vakaların üçünde psöriazis tanısı histopatolojik olarak doğrulandı. Romatoid artrit, ankilozan spondilit ve diğer spondiloartritlerde TNF-alfa inhibitörü kullanımına bağlı olarak psöriazis indüklenebilmektedir. En fazla püstüler form ile plak tipi psöriazis görülmekte ve palmoplantar dağılıma rastlanmaktadır.

(Turk J Rheumatol 2010; 25: 91-4)

Anahtar sözcükler: Ankilozan spondilit, psöriazis, romatoid artrit, spondiloartropati, TNF-alfa antagonistleri

Alındığı Tarih: 26.12.2008 Kabul Tarihi: 16.03.2009

ab, which are among monoclonal antibodies, and etanercept in receptor form. These agents are seen as relatively reliable but are associated with increase in infection and malignancy risk and may cause various skin lesions. Skin reactions stated to be associated with use of TNF- $\alpha$ inhibitors include erythema and edema at the site of injection, eczema, non-specific eruptions, erythema multiforme, bullous lesions, vasculitis, cutaneous lupus erythemato-

\author{
sus, and skin malignancies (1-4).
}

Tumor necrosis factor- $\alpha$ (TNF- $\alpha$ ) is a cytokine that plays an important role in the pathogenesis of autoimmune inflammatory diseases. Inhibition of TNF- $\alpha$ ensures significant recovery in disease activity in immune-mediated inflammations like rheumatoid arthritis (RA), ankylosing spondylitis (AS), Crohn disease and psoriatic arthritis (PsA). TNF- $\alpha$ inhibitors include infliximab and adalimum- 
TNF- $\alpha$ cytokine, which plays a role in the pathogenesis of immune inflammatory diseases, is also considered to have a key role in the pathophysiology of psoriasis (5). Both etanercept, which is a recombinant soluble human TNF receptor protein, and infliximab, which is a chimeric anti-TNF- $\alpha$ monoclonal antibody, have been used in psoriasis and PsA treatment successfully (4-6). Although they are used in psoriasis treatment, psoriasis cases have been reported in the last few years as developing due to the use of TNF- $\alpha$ inhibitors in RA, AS and other spondyloarthritides (3-5). These agents are reported to induce psoriasis or to worsen psoriatic skin lesions. Inducement of psoriasis may be seen as an acceptable side effect due to the benefits gained from anti-TNF- $\alpha$ treatment in patients with spondyloarthropathies $(7,8)$.

In the literature, psoriatic lesions that develop following use of TNF- $\alpha$ inhibitors was reported in two female patients with RA, one of whom used infliximab and the other etanercept, with development of lesions in the first three months of treatment (6). Psoriasis diagnosis in these patients was also verified histopathologically. Similar cases were reported later in the literature. Palmoplantar distribution, pustulous form and plaque type psoriasis are the cutaneous reactions most frequently occurring in connection with TNF- $\alpha$ blockers $(3,7,9,10)$.

In this case series, we present four cases with diagnosis of AS or RA who developed psoriasis caused by the use of TNF- $\alpha$ inhibitor. One of the cases had psoriatic skin lesions following use of two different TNF- $\alpha$ inhibitors.

\section{Case Presentation}

Case 1: Infliximab treatment was started in this male patient at the age of 31 in October 2006, upon severe disease activity (Bath AS Disease Activity Index, BASDAI=9.28). He had been followed with AS diagnosis for three years. Erythematous squamous lesions were seen on both upper and lower limbs in the $2^{\text {nd }}$ week of

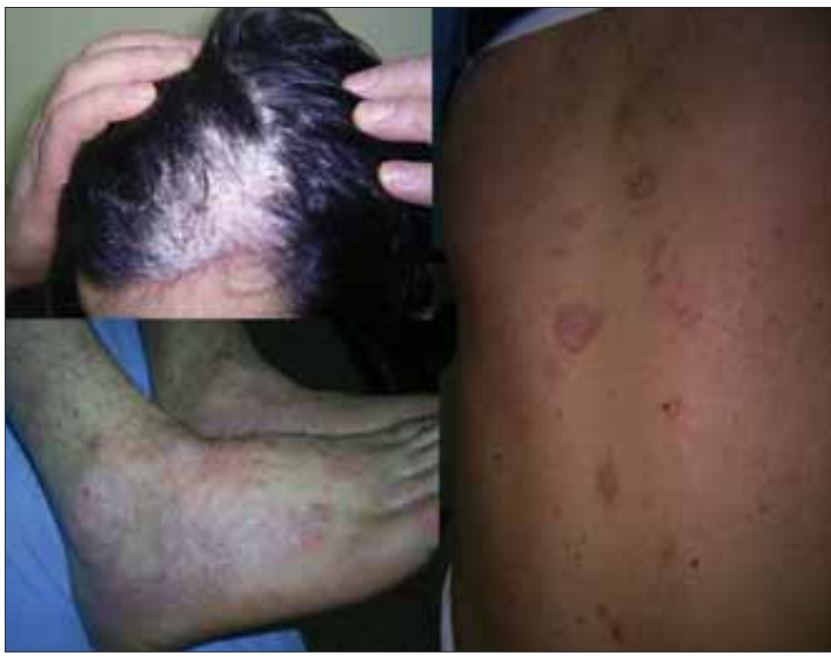

Figure 1. Psoriatic skin lesions of the patient around the scalp, back and ankles treatment. A decrease in lesions was observed at the end of treatment. However, since the disease progressed very actively, etanercept treatment was started two months later. Upon development of common psoriatic lesions on the entire body and limbs, becoming intensive on the scalp in the $1^{\text {st }}$ month of treatment (Figure 1), the patient was consulted to the Dermatology Clinic. Skin biopsy was performed and was reported as consistent with psoriasis. On the recommendation of the Dermatology Clinic, the treatment was ceased and clear recovery of the lesions was observed.

Case 2: This female patient, aged 53 years, had a 31-year history of RA. Etanercept treatment was started in January 2007 in addition to methotrexate upon failure in fully controlling disease activity with other diseasemodifying anti-rheumatic drugs (DMARDs). Erythematous squamous lesions were observed around both ankles in the $2^{\text {nd }}$ month of treatment. Skin biopsy was reported as psoriasiform dermatitis. Although treatment cessation was not recommended, the patient did not want to continue. The lesions recovered fully after treatment was stopped.

Case 3: In a female patient aged 34 years with a 16-year history of AS, infliximab treatment was started in March 2006 due to failure in controlling disease activity with other DMARDs. Palmar psoriatic lesions were seen on both hands in the $10^{\text {th }}$ month of treatment. Topical treatment was started for the patient, who was being followed in the Dermatology Clinic, and it was suggested that she continue treatment. Infliximab treatment was stopped at the patient's request and the lesions fully recovered.

Case 4: In a female patient aged 40 years with a 15-year history of AS, infliximab treatment was started in July 2006 upon severe disease activity. Pustulous lesions developed on her hands and feet in the 26th month of treatment (Figure 2). The patient was transferred to the Dermatology Clinic and topical treatment was started

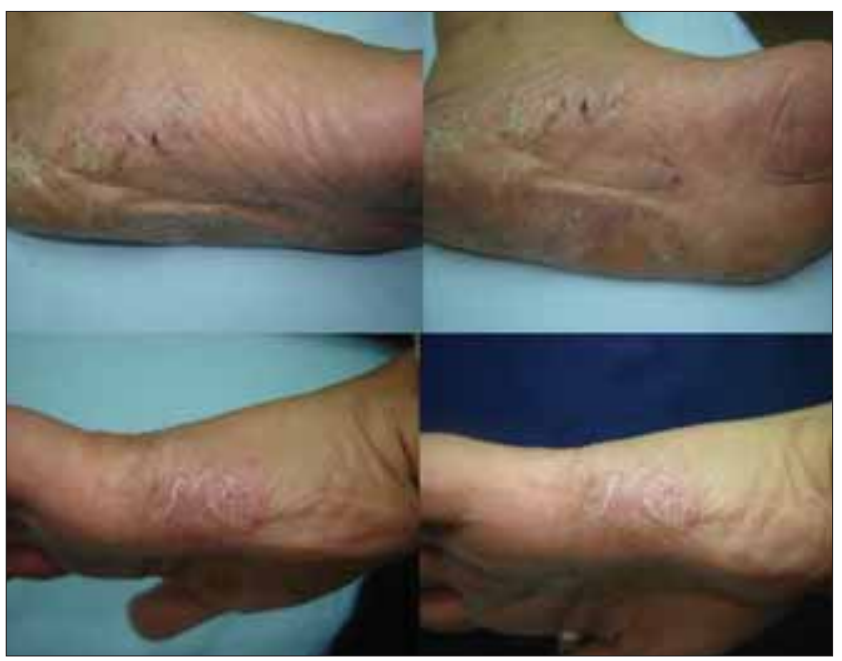

Figure 2. Psoriatic skin lesions seen on the hand and foot of the patient 
after diagnosis of pustulous psoriasis. Cessation of infliximab treatment was not suggested. No increase in the lesions was observed during follow-up.

In three of the patients, diagnosis of psoriasis was verified histopathologically. One patient did not consent to biopsy. The third and fourth cases were sisters, and four of the six siblings were being followed with a diagnosis of AS. The patients had no personal or family history of psoriasis.

\section{Discussion}

Various skin reactions may occur in connection with use of TNF- $\alpha$ inhibitors, including erythema, non-specific eruptions, edema, bullous lesions, and vasculitis in the injection zone. It was reported that skin lesions developed in $10 \%$ of the patients receiving anti-TNF treatment, including eczema, drug eruptions, drug induced systemic lupus erythematosus, dermatomyositis, lymphamatoid papulosis-like eruptions, and psoriasis (11).

According to the literature, Dereure et al. (6) were the first to report development of psoriatic skin lesions in connection with use of infliximab and etanercept in their study in 2004 involving two patients with RA. Similar cases were published later (1, 2, 4, 7, 9, 10, 12-17). Two cases were reported in Turkey, one of them a patient with RA using etanercept and the other with AS receiving infliximab treatment $(18,19)$.

In a Medline search performed by Grinblat et al. (3), they identified 50 cases with psoriasis or psoriasiform skin lesions associated with use of TNF- $\alpha$ inhibitor during the period April 2005 to February 2007. The most frequently seen disease among these cases was determined as RA (56\%), followed by AS (22\%) and inflammatory bowel disease (14\%). Plaque psoriasis was reported as the most frequently seen skin lesion, followed by pustulous form. Other involvements likely to be seen were reported as nail involvement and guttate psoriasis. Sixty-six percent of the patients were found to use infliximab, 34\% etanercept and $20 \%$ adalimumab. In some cases, development of psoriasis was observed following use of more than one type of TNF- $\alpha$ inhibitor as well. Symptoms were seen as a late event after start of TNF- $\alpha$ inhibitor in general. However, since time interval varied significantly in the cases, no average time was determined for symptom onset. Lesions recovered after treatment cessation in all patients, and were constant while treatment was continuing (3).

Harrison et al. (5) conducted a Medline search of patients with RA receiving anti-TNF treatment to determine those that developed psoriasis, and they identified 41 cases; psoriasis developed in the first nine months of treatment in these cases (average period of six months). However, they also reported cases in whom psoriasis developed as soon as within one week or as late as 62 months. While adalimumab was the latest agent used, it was observed to cause psoriasis as frequently as infliximab and etanercept. In our cases, lesions developed in a minimum of two weeks and maximum of 26 months following anti-TNF treatment. Harrison et al. (5) found 25 psoriasis cases between January 2001 and July 2007 in the study they carried out to determine psoriasis incidence rate in the patients with RA who received anti-TNF treatment by accessing the records of the British Society for Rheumatology. No psoriasis case was seen in the control group using DMARD. Psoriasis incidence in the patients with RA receiving anti-TNF treatment was found as $1.04 / 1000$ persons per year (5).

While the reasons for the occurrence of psoriasis following anti-TNF treatment have not yet been determined, various assumptions have been suggested. One is the possibility that these patients in actuality have PsA, mistakenly diagnosed as RA or AS. It was also stated that development of cutaneous side effects might be caused by bacterial infections. Furthermore, it was suggested that psoriasis might occur in association with other medications used and that some drug eruptions like exanthematous pustulosis might imitate psoriasis $(3,5)$.

Psoriatic skin lesions seen as side effects were associated with use of TNF- $\alpha$ inhibitors $(7,9)$. That is, development of lesions does not depend on a specific TNF- $\alpha$ inhibitor, but blockage of TNF- $\alpha$. As in the first case in this study, observation of psoriatic lesions with multiple TNF- $\alpha$ inhibitors in some cases supports the class effect of TNF- $\alpha$ inhibitors, as stated in the literature. In addition, the fact that two of our cases with AS were siblings suggests a role of genetic predisposition in the occurrence of this side effect.

Immunologic reasons are emphasized mostly with respect to the increase in psoriasis developing paradoxically following anti-TNF treatment. This is stated to be related with the changing immunity that occurs in connection with inhibition of TNF activity in predisposed individuals. It is reported that anti-TNF treatment increases activation of autoreactive $\mathrm{T}$ cells under certain conditions and thus causes tissue damage via autoimmune mechanisms. As in the case of lupus-like syndromes or development of anti-nuclear antibody induced by antiTNF, the reason may be alteration in inflammatory immune response $(13,16)$.

In patients receiving chronic anti-TNF treatment, cytokine imbalance between TNF- $\alpha$ and interferon- $\alpha$ was suggested as having a key role in the development of psoriatic lesions $(3,20)$. Other important cytokines like interleukin (IL)-15, 17 and 12-23 have a role in the psoriasis pathogenesis, and chronic anti-TNF treatment may affect immunoregulator pathways of these cytokines and may cause formation of psoriasis or psoriasiform lesions (20).

In the treatment of psoriatic lesions occurring in connection with use of TNF- $\alpha$ inhibitors, lesions were reported to recover upon cessation of the agents. In some cases, topical treatment started for psoriasis was sufficient with- 
out stopping treatment, while in other cases, the TNF- $\alpha$ inhibitor was replaced $(2-4,6,13,15)$.

In conclusion, psoriasis is induced or psoriatic skin lesions may worsen in connection with the use of TNF- $\alpha$ inhibitor in patients with RA, AS and other spondyloarthropathies. The most common form of psoriasis seen in connection with anti-TNF treatment is pustulous form and plaque type with palmoplantar distribution.

\section{Conflict of Interest}

No conflict of interest is declared by authors.

\section{References}

1. Beuthien $\mathrm{W}$, Mellinghoff $\mathrm{HU}$, von Kempis J. Skin reaction to adalimumab. Arthritis Rheum 2004; 50: 1690-2.

2. Kary $S$, Worm M, Audring $H$, Huscher $D$, Renelt $M$, Sorensen $\mathrm{H}$, et al. New onset or exacerbation of psoriatic skin lesions in patients with definite rheumatoid arthritis receiving tumour necrosis factor alpha antagonists. Ann Rheum Dis 2006; 65: 405-7.

3. Grinblat B, Scheinberg $M$. The enigmatic development of psoriasis and psoriasiform lesions during anti-TNF therapy: a review. Semin Arthritis Rheum 2008; 37: 251-5.

4. Cohen JD, Bournerias I, Buffard V, Paufler A, Chevalier X, Bagot $M$, et al. Psoriasis induced by tumor necrosis factoralpha antagonist therapy: a case series. J Rheumatol 2007; 34: 380-5.

5. Harrison MJ, Dixon WG, Watson KD, King Y, Groves R, Hyrich $\mathrm{KL}$, et al. Rates of new-onset psoriasis in patients with rheumatoid arthritis receiving anti-TNF $\alpha$ therapy. Results from British Society for Rheumatology Biologics Register. Ann Rheum Dis 2009; 68: 209-15.

6. Dereure O, Guillot B, Jorgensen C, Cohen JD, Combes B, Guilhou JJ. Psoriatic lesions induced by antitumour necrosis factor-alpha treatment: two cases. Br J Dermatol 2004; 151: 506-7.

7. Richette $\mathrm{P}$, Viguier $\mathrm{M}$, Bachelez $\mathrm{H}$, Bardin T. Psoriasis induced by anti-tumor necrosis factor therapy: A class effect? J Rheumatol 2007; 34(2): 438-9.

8. Borras-Blasco J, Gracia-Perez A, Nunez-Cornejo C, RosiqueRobles JD, Mateu-Puchades A, Castera MD, et al. Exacerbation of psoriatic skin lesions in a patient with psoriatic arthritis receiving adalimumab. J Clin Pharm Ther 2008; 33(3): 321-5.
9. Roux $\mathrm{CH}$, Brocq O, Leccia N, Giacchero D, Breuil V, Albert C, et al. New-onset psoriatic palmoplantaris pustulosis following infliximab therapy: a class effect? J Rheumatol 2007; 34: 434-7.

10. Grinblat B, Scheinberg M. Unexpected onset of psoriasis during infliximab treatment: comment on the article by Beuthien et al. Arthritis Rheum 2005; 52: 1333-4, author reply 1334.

11. Aslanidis S, Pyrpasopoulou A, Leontsini M, Zamboulis C. Anti-TNF-alpha induced psoriasis: case report of an unusual adverse event. Int J Dermatol 2006; 45: 982-3.

12. Sfikakis PP, Iliopoulos A, Elezoglou A, Kittas C, Stratigos A. Psoriasis induced by anti-tumor necrosis factor therapy: a paradoxical adverse reaction. Arthritis Rheum 2005; 52: 2513-18.

13. Lee HH, Song $\mathrm{IH}$, Friedrich $\mathrm{M}$, Gauliard A, Detert J, Röwert J, et al. Cutaneous side-effects in patients with rheumatic diseases during application of tumour necrosis factor- $\alpha$ antagonists. Br J Dermatol 2007; 156: 486-91.

14. de Gannes GC, Ghoreishi M, Pope J, Russell A, Bell D, Adams $S$, et al. Psoriasis and pustular dermatitis triggered by TNF- $\alpha$ inhibitors in patients with rheumatologic conditions. Arch Dermatol 2007; 143: 223-31.

15. Pirard D, Arco D, Debrouckere V, Heenen M. Anti-tumor necrosis factor alpha-induced psoriasiform eruptions: three further cases and current overview. Dermatology 2006; 213: 182-6.

16. Bosch RI, Amo Ndel V, Manteca CF, Cirtina EL, Polo RG, Courel LG. Psoriasis induced by anti-TNF probably not so uncommon. J Clin Rheumatol 2008; 14: 128.

17. Takahashi $H$, Hashimoto $Y$, Ishida-Yamamoto $A$, Ashida $T$, Kohgo $Y$, lızuka H. Psoriasiform and pustular eruption induced by infliximab. J Dermatol 2007; 34: 468-72.

18. Sari I, Akar S, Birlik M, Sis B, Onen F, Akkoc N. Anti-tumor necrosis factor alpha-induced psoriasis. J Rheumatol 2006; 33: $1411-4$.

19. Bal A, Gurcay E, Aydog E, Umay E, Tatlican S, Cakci A. Onset of psoriasis induced by infliximab. J Clin Rheumatol 2008; 14: 128-9.

20. Scheinberg M, Goncalves DP, Laurindo IMM. Anti-TNF agents inducing psoriasis. A recognized adverse effect. J Clin Rheumatol 2008; 14: 130. 